tion of the Labour government of 1964 that Britain's four principal manufacturers of power generation equipment then were individually too small to compete internationally and collectively too many to survive; by coaxing and coercion, they were made to merge. The result is a business of extraordinary diversity - it will make you a domestic refrigerator, a computer-aided tomography scanner or a military radar - which has been kept intact and profitable only by the talented administration of its chief executive, Lord Weinstock.

But the conglomerate has failed to make a distinctive mark in any single field; Marconi, technically GEC's pride, conspicuously failed last year to develop an early-warning airborne radar to the British defence ministry's specification (the business went to Boeing instead). Another defect is that GEC first accumulated and has since kept liquid reserves of $£ 1,500$ million. But should not companies be thrifty, salting away money for a rainy day? Not if the implication is that they are so dismayed by the difficulties of making money in their own businesses that they ask the banks to try instead. The truth is that GEC has grown too slowly, almost certainly because it has put too little of its own resources into self-financed (as distinct from military) research and development.

Now there is a shake-up on the way. Three years ago, GEC awoke from its cautious lethargy and tried to buy the British telecommunications manufacturer Plessey, but was thwarted by the defence ministry's argument (to the Monopolies and Mergers Commission) that competition among defence contractors would be thereby curtailed. Last year, GEC instead merged its own telecommunications business with Plessey's, but then, this year, cheekily combined with Siemens of West Germany in a second attempt to buy Plessey. That has brought the roof down on its head. Plessey is working hard to recruit support for an attempt to take over GEC, which has been stampeded into merging many of its business with the comparable European businesses of GE of the United States.

The company's misfortunes are partly self-inflicted, partly caused by successive British governments. GEC, like Siemens and GE, began life with the commercialization of electricity a century ago, and became a conglomerate because electricity turned out to have diverse applications. But, for twenty years, GEC has been managed as a collection of separate businesses. That should have given it an advantage over its competitors in being able easily to hive off its activities to others prepared to back their conviction that they could do better with them by paying above the odds for the opportunity. But staying big has been counted more important.

Successive governments have fortified GEC in its complacency by their shortsightedness over defence research. The late Sir Ieuan Maddock, when chief scientist at the then Ministry of Technology, was forever asking why the lion's share of British governments' research and development expenditure should go for aerospace and associated electronics, mostly for the military. The decision to oppose the Plessey merger three years ago was falsely predicated on the belief that the British services must always be equipped by British manufacturers. It would have been wiser if the government had been pressing for a European understanding that the rules of European free trade should also apply to defence procurement. That has now become an urgent need.

Meanwhile, the air is filled with talk of what is called "industrial logic", mostly from people whose skill is the management of money. The calculation in 1964 that the British market could not support four power-generation manufacturers may have been correct, but "industrial logic" would have required that the four should compete with each other for survival; the outcome might have been a manufacturer capable of winning business from elsewhere as well as Britain. In other fields within GEC's present ambit - consumer electronics, for example - there can have been no danger of over-competition a quarter of a century ago. Putting nearly all of Britain's eggs into an oversized com- pany has allowed West German, Italian, Scandinavian and Japanese manufacturers to win handsome prizes. The whole sorry episode should be a reminder to those who talk of industrial logic that success in industry is an empirical, not an abstract, business. The winners are those who succeed in competition with each other. Selling prices matter, but so do quality and performance, all of which are best ensured by intelligent research and development.

\section{Research in hazard}

\section{Last week's US budget promises generosity to science, but only the Congress can decide.}

LAST week's valedictory budget from President Ronald Reagan is no less what had been expected of him than the intended tearjerker of a speech he delivered to the United States a few days afterwards. For the budget, like the speech, has an olympian quality of detachment. Defence spending would increase (but modestly) and, within that, spending on the Strategic Defense Initiative would also be increased. The National Aeronautics and Space Administration would have the funds to build its space station, the Department of Energy would be able to make a start on the Superconducting Super Collider (and the clean-up of its military reactors) and general support for basic science (through the National Science Foundation) would also be increased. So how does the federal deficit affect these plans? On paper, it seems simple. If the cost of social programmes, Medicare and the like, is reduced by $\$ 30,000$ million, the requirements of Gramm-Rudman can be satisfied for another year. The likelihood that a Congress controlled by Democrats will accept this neat solution may be small, but that will be for President George Bush to worry about when he takes over this Friday.

The danger in this process is that it puts the eminently desirable elements of the outgoing administration's programme in hazard to the uncertainties of a political process that has not yet begun. The next step is for the new president to say how he would amend the Reagan budget. Only then will the Congress begin to say how it will require the package to be changed. It would not be surprising (but par for the course) if the exact balance of the budget for the year beginning on 1 October is not known until after it has begun. In the circumstances, it is natural that the presidents of the US national academies (science, medicine and engineering) should have given the new administration their advice on how to manage science.

The Reagan adminstration's calculation that more spending on basic science would, in the long run, contribute to the competitiveness of US industry and the general wellbeing of society is correct, and in that spirit much has been done to increase, for example, the budget of the National Science Foundation. But some of the more expensive items in what is generally considered to be the science budget, the planned space station for example, are hardly science at all, while there is no known rational basis for telling in advance whether projects of that kind are more likely to yield economic benefits. A stronger science advisory apparatus at the White House could help to open such questions to discussion. Dr Frank Press's argument last year that the time has come when the scientific community in the United States must help to determine priorities is entirely apt.

But will it not be bad for science that one part of the community should be seen to be sceptical of another's pet projects? As in Britain a decade ago, the reality of government support for research and development is determined both by the sums of money set aside in budgets and by the value of what the money will buy when the time comes for spending it. No purpose will be served, in the United States, if promised spending is undermined by rampant inflation or by one of the other consequences of a continuing federal deficit on the scale bequeathed by Reagan to Bush. 